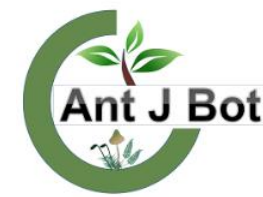

Received : 21.08.2019 Accepted : 22.09.2019 Online $\quad: 25.09 .2019$

\title{
Determination of fatty acid profile and mineral contents of Tricholomopsis rutilans collected from Yozgat
}

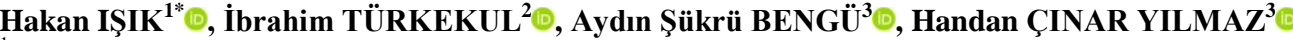 \\ ${ }^{1}$ Tokat M.Emin Saraç Anatolian Religious High School, 60030, Tokat, Turkey \\ ${ }^{2}$ Gaziosmanpaşa University, Faculty of Science, Department of Biology, 60200, Tokat, Turkey \\ ${ }^{3}$ Bingöl University, Vocational School of Health Services, Department of Medical Services and Techniques, \\ Program of Medical Laboratory Techniques, 12000, Bingöl, Turkey \\ *hakanbiyoloji@gmail.com
}

\section{Yozgat'tan toplanan Tricholomopsis rutilans örneklerinin yağ asidi profili ve mineral içeriğinin belirlenmesi}

\begin{abstract}
This study was carried out to determine the content of some minerals and fatty acids in Tricholomopsis rutilans (Schaeff.) Singer samples. Tricholomopsis rutilans is a saprophytic mushroom growing on or around conifer stumps and characterized by white spore print, yellow gills, a large yellow cap and yellow stipe entirely covered with red to purplish red scale and fibrils. It is an edible mushroom, although the taste is not nice. The analysed mushroom samples, were collected from different localities of Yozgat province during field trips between 2012-2016 years. Mineral analysis were performed by ICPMS, and fatty acids were tested by Gas Chromatography-Mass Spectrometry system (GC-MS). Seven different fatty acids (miristic, pentadecanoic, palmitic, palmitoleic, stearic, oleic, and linoleic acid) and six different minerals ( $\mathrm{Cu}, \mathrm{Mn}, \mathrm{Zn}, \mathrm{Fe}, \mathrm{Mg}$, $\mathrm{Na}$ ) have been determined in mushroom samples. Oleic and linoleic acid were the major fatty acids with proportions $39.04 \%$ and $37.09 \%$, respectively. $\mathrm{Na}$ and $\mathrm{Mg}$ were found to be the most abundant minerals with $126.895 \mathrm{mgkg}^{-1} \mathrm{and}^{754.605} \mathrm{mgkg}^{-1}$, respectively among the determined minerals.
\end{abstract}

Key words: Tricholomopsis rutilans, fatty acids, mineral content, ICP-MS, GC-MS

Özet: Bu çalışma Tricholomopsis rutilans (Schaeff.) Singer örneklerinde bazı mineral ve yağ asitlerinin içeriğini belirlemek amacıyla yapılmıştır. Tricholomopsis rutilans konifer kütüklerinin üzerinde veya çevresinde gelişen saprofit bir mantardır ve beyaz spor baskısı, sarı jiller ve üzerleri tamamiyle kırmızı-morumsu kırmızı pullar ve fibriller ile kaplı büyük sarı şapka ve sarı sapla karakterize edilir. Tadı güzel olmasa da, yenilebilir bir mantardır. Analiz edilen mantar örnekleri 2012-2016 yılları arasında yapılan gezilerde Yozgat ilinin farklı bölgelerinden toplanmıștır. Mineral analizleri ICP-MS ile yağ asitleri ise gaz kromatografi-kütle spektrometre sistemi (GC-MS) ile test edildi. Analiz sonuçlarına göre mantar örneklerinden yedi farklı yağ asidi (miristik, pentadekanoik, palmitik, palmitoleik, stearik, oleik ve linoleik asit) ve altı farklı mineral (Cu, Mn, $\mathrm{Zn}, \mathrm{Fe}, \mathrm{Mg}$, $\mathrm{Na}$ ) tespit edilmiştir. Oleik ve linoleik asit, $39.04 \%$ ve $37.09 \%$ oranlarla major yağ asitleri olarak belirlenmiştir. Tespit edilen mineraller arasında $\mathrm{Na}$ ve $\mathrm{Mg}$ 'un, $126.895 \mathrm{mgkg}^{-1}$ ve $754.605 \mathrm{mgkg}^{-1}$ lik oranlarla en bol bulunan mineral mineraller olduğu belirlenmiștir.

Anahtar Kelimeler: Tricholomopsis rutilans, yağ asitleri, mineral içeriği, ICP-MS, GC-MS

\section{Introduction}

The role of mushrooms in nutrition and complementary treatment methods is rapidly increasing. The mushrooms (especially belonging to ascomycota and basidiomycota) have been used for a long time because of their medicinal properties (antioxidant, antimicrobial, anticancer, immunostimulatory and anti-inflammatory activity etc.) in folk medicine of China, Japan and other countries from the Far East. It is believed from researchers that biomacromolecules (polysaccharides or polysaccharideprotein complexes etc.) produced by mushrooms can inhibit tumor growth. Also they can prevent carcinogenesis and tumour metastasis. In accordance with this information, it has been reported that polysaccharide extracts of Tricholomopsis rutilans have anticancerogenic, antioxidant and antiinflammatory effects (Hilszczańska, 2012; Rahi and Malik, 2016). Wild edible mushrooms are regarded as a healthy food source due to their high mineral, protein, fiber, unsaturated fatty acids and vitamins contents, and low-fat and calorie levels. They are an important option for vegetarian diets and people who want to feed with a protein rich diet (Orsine et al., 2012; Valverde et al., 2015).
Many studies have been made to investigate the chemical contents of mushrooms (Akyüz et al., 2011; Barros et al., 2008; Ergönül et al., 2012; Goyal et al., 2015; Bengü, 2019; Bengü et al., 2019). In these studies, saturated, monounsaturated and polyunsaturated fatty acids were determined in mushrooms. The results of the studies revealed that unsaturated fatty acids (UFA) are higher than saturated fatty acids. Accordingly, mushrooms are important nutrient sources for meeting the daily fatty acid needs of humans. The monounsaturated fatty acids (MUFAs) have attracted attentions in recent years due to their protective effects against heart diseases such as atherosclerosis. The nutritional value of fat in foods is determined by the amount of polyunsaturated fatty acids (PUFAs- especially linoleic and linolenic acid that are also called essential fatty acids) in their structure. Essential fatty acids (EFAs) are used in the synthesis of certain hormones, as well as preventing blood clotting and hypertension. They increases the blood circulation and contributes to the suitable distribution of cholesterol in human body (Kaur et al., 2012; Sokoła-Wysoczańska et al., 2018)

Many studies have shown in general that mushrooms are also important nutrients in terms of some major elements 
(potassium, phosphorus, calcium, sodium, magnesium etc.) and some trace elements (iron, zinc, copper, manganese, selenium etc.) too (Adejumo and Awosanya, 2005; Bernaś et al., 2006; Mallikarjuna et al., 2013; Mirończuk-Chodakowska et al., 2013). Trace /micro elements are very important for human body and other biological systems. Zinc $(\mathrm{Zn})$ is involved as a cofactor in the structure of approximately 300 enzymes in energy production and metabolism of carbohydrates, proteins and lipids. Manganese (Mn), as a cofactor of various enzymes involved in metabolic processes and manganese superoxide dismutase, is a trace element necessary for the healthy development and growth of the organism. It is essential for bone development, and metabolism of amino acids, carbohydrates and cholesterol. Iron (Fe) is involved in the structure of many organic compounds that have important functions in our body such as myoglobin, hemoglobin, cytochromes. Magnesium $(\mathrm{Mg})$ as major intracellular mineral is involved in many important structural, metabolic and physiological processes in biological systems such as the synthesis of proteins and nucleic acids, cell replication, to be cofactor for many enzymes, energy metabolism, complexing with ATP. Copper $(\mathrm{Cu})$ is used in oxidation reduction processes and removing free radicals from biological systems. Copper is involved in the structure of some important enzymes such as lysyl oxidase, cytochrome c oxidase, superoxide dismutase. These enzymes are called as copper enzymes. Sodium (Na) as major element of extracellular fluid is involved at the formation of osmotic pressure of blood and other body fluids, transport of certain nutrients through the plasma membrane such as amino acids, glucose, galactose, and excitability of nerve and muscle cells (Seo and Park, 2008; Angelova et al., 2011; Zabłocka-Słowińska and Grajeta, 2012; Mallikarjuna et al., 2013; Gupta, 2014; Strazzullo and Leclercq, 2014; Pietrzak-Fiećko et al., 2016; Al-Fartusie and Mohssan, 2017).

This present study aims to reveal the chemical composition of Tricholomopsis rutilans in terms of some minerals and fatty acids.

\section{Materials and Method}

\subsection{Collection and Identification of Mushroom Samples}

The mushroom samples identified as Tricholomopsis rutilans were collected from different localities of Yozgat province during the field trips between 2012-2016. The mushroom samples, photographed in their natural habitat, were brought to the laboratory for further processing. Spore traces of samples were obtained in laboratory and collection numbers were given. The fresh samples were dried and put into polyethylene bags. Their microscopic properties were investigated with the help of some chemical reagents under a light microscope. Using the obtained morphological and ecological characteristics of the samples, they were identified with the help of existing literature such as Phillips (1981), Breitenbach and Kränzlin (1991) and Jordan (1995).

\subsection{Fatty acid analysis}

The mineral and fatty acid contents of mushrooms were analyzed at Bingol University Central Research Laboratory. Christie (1990) was followed in the preparation of methyl esters of fatty acids, after some revisions. With some revision Hara and Radin (1978) was followed for lipid extraction. A gas chromatograph instrument with a FID and MS (GC-MS, Agilent 7890 GC/5970 MS Series-Santa Clara, CA, USA), and a high polarity capillary column (HP-88, $100 \mathrm{~m} \times 0.25 \mathrm{~mm}, 0.20$ um film (Part no: 112-88A7, Agilent, Santa Clara, CA, USA) was used for fatty acid analyzes. Helium was used as the carrier gas (helium at $1 \mathrm{mLmin}^{-1}$. at $120^{\circ} \mathrm{C}$ ). The injector temperature was set at $250{ }^{\circ} \mathrm{C}$, and the detector temperature at $250{ }^{\circ} \mathrm{C}$. The oven temperature was initially set at $120^{\circ} \mathrm{C}$ for $2 \mathrm{~min}$, and then raised to $250{ }^{\circ} \mathrm{C}$ at $5{ }^{\circ} \mathrm{C}$ $\mathrm{min}^{-1}$. Because hold time is 16 minutes, total analysis is 45 minutes. The detector gas was air set at $350 \mathrm{mLmin}^{-1}$, and hydrogen gas was set at $35 \mathrm{mLmin}^{-1}$. The detector make up gas was nitrogen at $35 \mathrm{mLmin}^{-1}$. Other conditions; split ratio is $1 / 10$, solvent delay time is 12 minutes, injection volume is $1 \mathrm{uL}$. Injection system with auto sampler was used.

\subsection{Mineral analysis}

All mineral analyzes were performed using the ICP-MS (PerkinElmer NexION 2000) instrument using the conditions in Table 1.

Table 1. ICP-MS conditions for mineral analysis

\begin{tabular}{|l|l|}
\hline Parameter/Component & Description / Value \\
\hline Nebulizer & MEINHARD ${ }^{\circledR}$ plus Glass Type C \\
\hline Nebulizer flow & Optimized for $<2 \%$ oxides \\
\hline Nebulizer gas flow rate & $0,93 \mathrm{~L} / \mathrm{min}$ \\
\hline Spray Chamber & $\begin{array}{l}\text { Glass cyclonic (baffled), } \\
2{ }^{\circ} \mathrm{C}\end{array}$ \\
\hline Injector & $2.0 \mathrm{~mm}$ i.d. \\
\hline Deflector voltage & $-12 \mathrm{~V}$ \\
\hline Analog stage voltage & $-1750 \mathrm{~V}$ \\
\hline RF Power & $1600 \mathrm{~W}$ \\
\hline Rinse time & $45 \mathrm{~second}$ \\
\hline Dwell time & $50 \mathrm{~ms}$ \\
\hline Aerosol Dilution & $\mathrm{Set} \mathrm{to} 2.5 \mathrm{x}$ \\
\hline Sample Delivery Rate & $350 \mu \mathrm{L} / \mathrm{min}$ \\
\hline Discriminator threshold & 26 \\
\hline $\begin{array}{l}\text { Alternating current (AC) } \\
\text { rod offset }\end{array}$ & -4 \\
\hline Cones & $\mathrm{Ni}$ \\
\hline Replicates & 3 \\
\hline
\end{tabular}

The studies have been made in the form of three repetitions and were averaged. The data of mineral analysis were reported as $\mathrm{mgkg}^{-1}$ and the results of fatty acids were reported as percentages.

\section{Results}

In the present study, fatty acids and mineral composition of Tricholomopsis rutilans were analyzed. The fatty acids in the structure of the mushroom samples were tested by GC-MS and different proportions of saturated fatty acids (SFA), MUFAs, and PUFAs were determined. The results for fatty acid composition were shown in Table 2 and Figure 1 as percentages.

In addition, the levels of total saturated, unsaturated, monounsaturated and polyunsaturated fatty acid in the tested samples are given in Table 3 and Figure 2. 
Table 2. Fatty acid levels of T. rutilans (\%)

\begin{tabular}{|l|r|}
\hline Myristic acid (C14:0) & 0.48 \\
\hline Pentadecanoic acid (C15:0) & 1.03 \\
\hline Palmitic acid (C16:0) & 17.14 \\
\hline Stearic acid (C18:0) & 4.18 \\
\hline SSFAs & 22.83 \\
\hline Palmitoleic acid (C16:1) & 1.04 \\
\hline Oleic acid (C18:1) & 39.04 \\
\hline Linoleic acid (C18:2) & 37.09 \\
\hline LUFAs & 77.17 \\
\hline
\end{tabular}

SFA: saturated fatty acid, UFA: unsaturated fatty acid

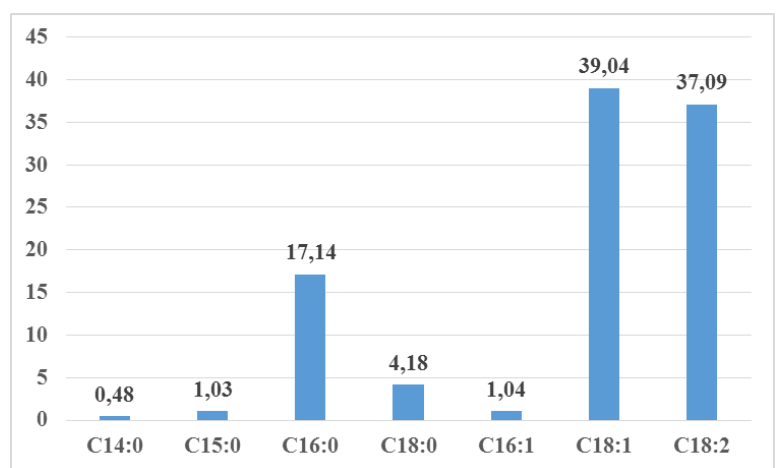

Figure 1. Fatty acid levels of T. rutilans (\%)

The minerals in the structure of $T$. rutilans samples were analyzed by ICP-MS and six different minerals $(\mathrm{Cu}, \mathrm{Mn}$, $\mathrm{Zn}, \mathrm{Fe}, \mathrm{Mg}, \mathrm{Na}$ ) were determined as $\mathrm{mgkg}^{-1}$ at different amounts. The mineral contents in fruiting bodies of $T$. rutilans are shown in Table 4 and Figure 3.

Table 3. Proportion of saturated, unsaturated, monounsaturated and polysaturated fatty acids of $T$. rutilans (\%)

\begin{tabular}{|c|c|}
\hline Total saturated fatty acids ( $\Sigma$ SFAs) & 22.83 \\
\hline Total unsaturated fatty acids ( $\Sigma$ UFAs) & 77.17 \\
\hline Total monounsaturated fatty acids ( $\Sigma$ MUFAs) & 40.08 \\
\hline Total polyunsaturated fatty acids ( $\Sigma$ PUFAs) & 37.09 \\
\hline
\end{tabular}

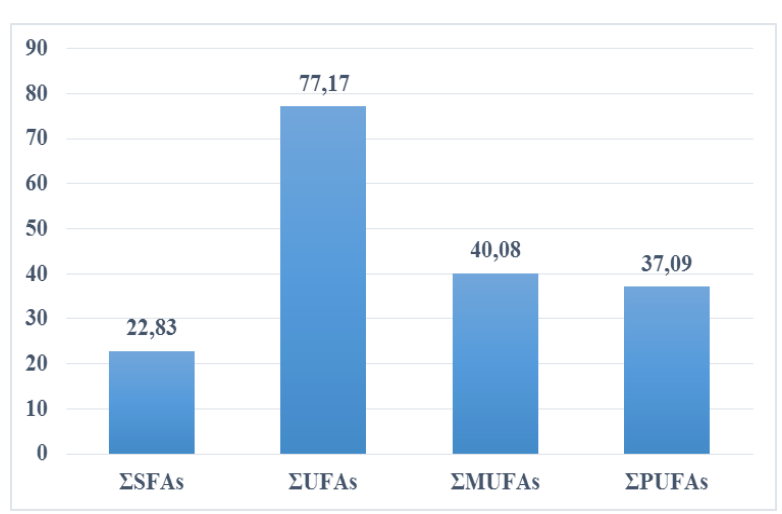

Figure 2. Proportion of saturated, unsaturated, monounsaturated and polysaturated fatty acids of $T$. rutilans (\%)

\section{Discussions}

According to the results, seven different fatty acids (four saturated fatty acids and three unsaturated fatty acids), with carbon chain lengths ranging from 14-18, have been detected in quantities ranging from $0.48 \%$ to $39.04 \%$ from
T. rutilans samples. Myristic, pentadecanoic, palmitic, stearic, palmitoleic, oleic and linoleic acid were found with proportions $0.48 \%, 1.03 \%, 17.14 \%, 4.18 \%, 1.04 \%$, $39.04 \%$, 37.09\%, respectively (Table 2, Figure 1). Myristic acid was found to be the lowest amount of fatty acid in our samples with proportions $0.48 \%$. Oleic acid was the major fatty acid with $39.04 \%$. Palmitic acid and linoleic acid were the other fatty acids to be at higher amounts with proportions $17.14 \%$ and $37.09 \%$, respectively. Linoleic acid which is a PUFAs can not be produced in the human body. So it is called essential fatty acids. $\Sigma$ UFAs amounts was higher than SFAs amount in our samples (Table 3, Figure 2). Our analysis results are consistent with the similar studies carried out by Yilmaz et al. (2006), Ergönül et al. (2012), Goyal et al. (2015), Doğan (2016) and Bengu (2019). All of them reported the amount of UFAs to be higher than SFAs. Yilmaz et al. (2006) determined the dominant fatty acid as linoleic acid in seven different wild mushroom species. Likewise Ergönül et al. (2012), reported linoleic acid as major fatty acid in Polyporus squamosus, Pleurotus ostreatus, Lactarius salmonicolor and Flammulina velutipes, and oleic acid in Russula anthracina and Boletus reticulatus samples. Goyal et al. (2015) also determined the linoleic acid as the most abundant fatty acid in Pleurotus sajor caju and Agaricus bisporus. Doğan (2016) reported the fatty acid contents of Terfezia boudieri and Lactarius vellereus, and presented palmitic, stearic, oleic, linoleic acids as the main fatty acids, among which linoleic acid was found as the major fatty acid. The results of a chemical analysis of some mushroom samples, also yielded linoleic acid as the major fatty acid for Suillus luteus and Coprinus atramentarius samples while it was oleic acid for Laetiporus sulphureus. On the other hand Çınar Y1lmaz and Bengü (2018) obtained different results from five different Lactarius species, than those discussed above. In their results the saturated fatty acid ratio was higher than the unsaturated fatty acid ratio. Also the dominant fatty acid was stearic acid (C18:0).

Table 4. Mineral content of fruiting bodies of T. rutilans $\left(\mathrm{mgkg}^{-1}\right.$ dry weight)

\begin{tabular}{|l|r|}
\hline Copper $(\mathrm{Cu})$ & 26.482 \\
\hline Iron $(\mathrm{Fe})$ & 55.729 \\
\hline Magnesium $(\mathrm{Mg})$ & 754.605 \\
\hline Manganese $(\mathrm{Mn})$ & 9.258 \\
\hline Zinc $(\mathrm{Zn})$ & 23.176 \\
\hline Sodium $(\mathrm{Na})$ & 126.895 \\
\hline
\end{tabular}

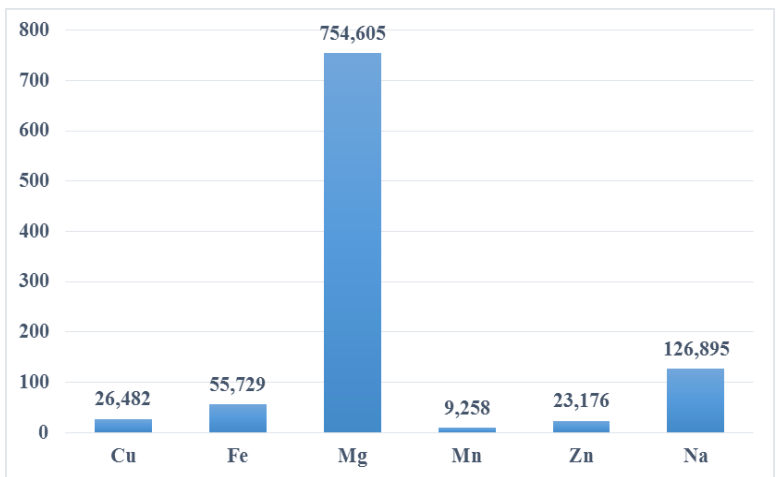

Figure 3. Mineral content of fruiting bodies of T. rutilans $\left(\mathrm{mgkg}^{-1}\right.$ dry weight) 
Mushrooms can contain large amounts of both macro and micro elements, in their fruiting bodies, that people should take from foods. We have determined some macro elements $(\mathrm{Na}, \mathrm{Mg})$ and micro elements (Fe, $\mathrm{Zn}, \mathrm{Cu}, \mathrm{Mn})$ in T. rutilans samples (Table 4 and Figure 3). We found $\mathrm{Cu}, \mathrm{Fe}, \mathrm{Mn}$ and $\mathrm{Zn}$ at lower amounts with the concentrations of 26.482, 55.729, 9.258, $23.176 \mathrm{mgkg}^{-1}$, respectively, and $\mathrm{Mg}$ and $\mathrm{Na}$ were at higher amounts with the concentration of 754.605 and $126.895 \mathrm{mgkg}^{-1}$, respectively. In our mushroom samples analyzed, the lowest mineral was measured as Mn with $9.258 \mathrm{mgkg}^{-1}$ while $\mathrm{Mg}$ was the highest with $754.605 \mathrm{mgkg}^{-1}$. Sesli and Tüzen (1999) reported the trace elements $(\mathrm{Pb}, \mathrm{Hg}, \mathrm{Cd}, \mathrm{Fe}$, $\mathrm{Zn}, \mathrm{Mn}, \mathrm{Cu}, \mathrm{As}$ and $\mathrm{Co}$ ), contents of two cultivated and 109 wild macrofungi specimens, and presented the $\mathrm{Fe}, \mathrm{Zn}$, $\mathrm{Mn}, \mathrm{Cu}$ amounts in T. rutilans as 67.5, 28.5, 19.1 and 82.1 $\mu \mathrm{g} / \mathrm{g}$, respectively. Regarding these four minerals, the highest mineral was $\mathrm{Cu}$, while $\mathrm{Fe}$ was measured as the highest one in our study. In a study carried out by Bengü (2019) on mineral values of Suillus luteus, Laetiporus sulphureus and Coprinus atramentarius, $\mathrm{Zn}, \mathrm{Fe}, \mathrm{Cu}, \mathrm{Mn}$ were determined in different amounts. In this study, the highest and lowest values of $\mathrm{Zn}$ were found in Coprinus atramentarius and Laetiporus sulphureus samples with $288.4 \mathrm{mgkg}^{-1}, 28.36 \mathrm{mgkg}^{-1}$ respectively. For the same mushrooms, the Fe values were $1183.6 \mathrm{mgkg}^{-1}, 162.92$ $\mathrm{mgkg}^{-1}$ respectively, the $\mathrm{Cu}$ values were $57.12 \mathrm{mgkg}^{-1}, 5.0$ $\mathrm{mgkg}^{-1}$ respectively, the $\mathrm{Mn}$ values were $64.2 \mathrm{mgkg}^{-1}$, $19.36 \mathrm{mgkg}^{-1}$ respectively. The highest values for these minerals were determined in Coprinus atramentarius samples. Kaya et al. (2017) determined the mineral content of eleven wild edible mushroom species, and observed the minimum and maximum values of $\mathrm{Cu}$ in Pleurotus ostreatus and Psathyrella candolleana with $15.57 \mathrm{mgkg}^{-1}$ and $60.43 \mathrm{mgkg}^{-1}$ respectively. The same values for $\mathrm{Zn}$ were reported to be $58.69 \mathrm{mgkg}^{-1}$ and 110.9 $\mathrm{mgkg}^{-1}$ in Coprinus comatus and Pleurotus ostreatus, for Mn with $7.115 \mathrm{mgkg}^{-1}$ and $138.2 \mathrm{mgkg}^{-1}$ in Cyclocybe cylindracea and Volvopluteus gloiocephalus, for $\mathrm{Mg}$ with $61.03 \mathrm{mgkg}^{-1}$ and $67.23 \mathrm{mgkg}^{-1}$ in Leucoagaricus leucothites and Lycoperdon molle, for $\mathrm{Fe}$ with 59.42 $\mathrm{mgkg}^{-1}$ and $585.3 \mathrm{mgkg}^{-1}$ in Leucoagaricus leucothites and Lycoperdon molle.

Wild edible mushrooms can be preferred due to their nutritional values as well as ease of accessibility and cheapness. However, the existance of poisonous mushrooms and the fact that most of the edible mushrooms in a region are not known by the local people, is an important problem. Mushrooms consumed in one region are not recognized in another region. Systematic studies and an increase in public awareness about edible fungi may increase the consumption of these valuable nutrient sources.

\section{Acknowledgments}

The authors would like to thank all expert staff of Bingol University Central Research Laboratory for their help at the chemical analysis. This study was presented as oral in $2^{\text {nd }}$ International Eurasian Conference on Biological and Chemical Sciences (EurasianBioChem 2019), 28-29 June 2019, Ankara-Turkey.

\section{References}

Adejumo TO, Awosanya OB (2005). Proximate and mineral composition of four edible mushroom species from South Western Nigeria. African Journal of Biotechnology 4: 1084-1088.

Akyüz M, Kırbağ S, Karatepe M, Güvenç M, Zengin F (2011). Vitamin and fatty acid composition of P. eryngii var. eryngii. Bitlis Eren University Journal of Science and Technology 1: 16-20.

Al-Fartusie FS, Mohssan SN (2017). Essential trace elements and their vital roles in human body. Indian Journal of Advances in Chemical Science 5(3): 127-136.

Angelova M, Asenova S, Nedkova V, Koleva-Kolarova R (2011). Copper in the human organism. Trakia Journal of Sciences 9(1): 88-98

Barros L, Cruz T, Baptista P, Estevinho LM, Ferreira ICFR (2008). Wild and commercial mushrooms as source of nutrients and nutraceuticals. Food and Chemical Toxicology 46: 2742-2747.

Bengü AŞ (2019). Some elements and fatty acid profiles of three different wild edible mushrooms from Tokat Province in Turkey. Progress in Nutrition 21(1): 189-193.

Bengü AŞ, Çınar Yılmaz H, Türkekul İ, Işık H (2019). Doğadan toplanan ve kültürü yapılan Pleurotus ostreatus ve Agaricus bisporus mantarlarının toplam protein, vitamin ve yağ asidi içeriklerinin belirlenmesi. Turkish Journal of Agricultural and Natural Sciences 6(2): 222-229.

Bernaś E, Jaworska G, Lisiewska Z (2006). Edible mushrooms as a source of valuable nutritive constituents. Acta Scientiarum Polonorum, Technologia Alimentaria 5(1): 5-20.

Breitenbach J, Kränzlin F (1991). Fungi of Switzerland. Vol: 3, Boletes and Agarics. Luzern: Verlag Mykologia.

Christie WW (1990). Gas chromatography and lipids: A practical guide. Scotland: The Oily Press Ltd.

Çınar Yılmaz H, Bengü AŞ (2018). The investigation of fatty acids and mineral profiles of some edible Lactarius species (L. deliciosus, L. deterrimus, L. salmonicolor, L. sanguifluus, L. semisanguifluus) in the Uşak/Turkey province of Aegean Region. Biological Diversity and Conservation 11(1): 95-104.

Doğan HH (2016). Fatty acid compositions of two mushrooms in Turkey. International Journal of Recent Scientific Research 7(4): 10017-10020.

Ergönül PG, Ergönül B, Kalyoncu F, Akata I (2012). Fatty acid compositions of five wild edible mushroom species collected from Turkey. International Journal of Pharmacology 8(5): 463-466.

Hara A, Radin NS (1978). Lipid extraction of tissues with a low-toxicity solvent. Analytical Biochemistry 90: $420-426$. 
Goyal R, Grewal RB, Goyal RK (2015). Fatty acid composition and dietary fibre constituents of mushrooms of North India. Emirates Journal of Food and Agriculture 27(12): 927-930.

Gupta CP (2014). Role of iron (Fe) in body. Journal of Applied Chemistry 7(11): 38-46.

Hilszczańska D (2012). Medicinal properties of macrofungi. Leśne Prace Badawcze 73(4): 347-353.

Jordan M (1995). The encyclopedia of fungi of Britain and Europe. London: Frances Lincoln.

Kaur N, Chugh V, Gupta AK (2012). Essential fatty acids as functional components of foods- a review. Journal of Food Science and Technology 51(10): 2289-2303.

Kaya A, Kılıçel F, Karapınar HS, Uzun Y (2017). Mineral contents of some wild edible mushrooms. The Journal of Fungus 8(2): 178-183.

Mallikarjuna SE, Ranjini A, Haware DJ, Vijayalakshmi MR, Shashirekha MN, Rajarathnam S (2013). Mineral composition of four edible mushrooms. Journal of Chemistry 2013:1-5.

Mirończuk-Chodakowska I, Socha K, Witkowska AM, Zujko ME, Borawska MH (2013). Cadmium and Lead in wild edible mushrooms from the Eastern Region of Poland's 'Green Lungs'. Polish Journal of Environmental Studies 22(6): 17591765.

Orsine JVC, Novaes MRCG, Asquieri ER (2012). Nutritional value of Agaricus sylvaticus; mushroom grown in Brazil. Nutrición Hospitalaria 27(2): 449-455.

Phillips R (1981). Mushrooms and other fungi of Great Britain \& Europe. London: Pan Books Ltd.

Pietrzak-Fiećko R, Gałgowska M, Bakuła S (2016). Fatty acid composition in wild Boletus edulis from Poland. Italian Journal of Food Science 28: 402-411.

Rahi DK, Malik D (2016). Diversity of mushrooms and their metabolites of nutraceutical and therapeutic significance. Journal of Mycology 2016: 1-18.

Seo JW, Park TJ (2008). Magnesium metabolism. Electrolyte \& Blood Pressure 6:86-95.

Sesli E, Tüzen M (1999). Levels of trace elements in the fruiting bodies of macrofungi growing in the East Black Sea region of Turkey. Food Chemistry 65: 453-460.

Sokoła-Wysoczańska E, Wysoczański T, Wagner J, Czyż K, Bodkowski R, Lochyński S, Patkowska-Sokoła B (2018). Polyunsaturated fatty acids and their potential therapeutic role in cardiovascular system disorders -A Review. Nutrients 10: 1561.

Strazzullo P, Leclercq C (2014). Sodium. Advances in Nutrition 5(2): 188-190.

Valverde ME, Hernández-Pérez T, Paredes-López O (2015). Edible mushrooms: Improving human health and promoting quality life. International Journal of Microbiology 2015: 1-14.

Yilmaz N, Solmaz M, Türkekul İ, Elmastaş M (2006). Fatty acid composition in some wild edible mushrooms growing in the middle Black Sea region of Turkey. Food Chemistry 99: 168-174.

Zabłocka-Słowińska K, Grajeta H (2012). The role of manganese in etiopathogenesis and prevention of selected diseases. Postepy Hig Med Dosw 66: 549-553.

Cite this article: Işık H, Türkekul İ, Çınar Yılmaz H, Bengü AŞ (2019). Determination of fatty acid profile and mineral contents of Tricholomopsis rutilans collected from Yozgat. Anatolian Journal of Botany 3(2): 64-68. 